\title{
QUANTITATIVE ASSESSMENT OF SOCIAL VULNERABILITY FOR LANDSLIDE DISASTER RISK REDUCTION USING GIS APPROACH (Case study: Cilacap Regency, Province of Central Java, Indonesia)
}

\author{
Arwan Putra Wijaya ${ }^{1}$, Jung-Hong Hong ${ }^{1 *}$ \\ ${ }^{1}$ Dept. of Geomatics, National Cheng Kung University, Tainan, Taiwan \\ - arwan.pw08@gmail.com,junghong@mail.ncku.edu.tw \\ Commission IV, WG IV/3
}

KEYWORDS: Quantitative assessment, Social vulnerability, Disaster risk reduction, Education, Unemployment

\begin{abstract}
:
Social vulnerability is an important aspect in determining the level of disaster risk in a region. Social vulnerability index (SoVI) is influenced by several supporting factors, such as age, gender, health, education, etc. When different sets of parameters are considered, the SoVI analyzed results are likely to be also different from one to another. In this paper, we will discuss the quantitative assessments of SoVI based on two different models. The first model, proposed by Frigerio, I., et al. (2016), is used to analyze the spatial diversity of social vulnerability due to seismic hazards in Italy. The second model is based on the regulations of the head of the National Disaster Management Agency (BNPB) No. 2 of 2012. GIS is used to present and compare the results of the two selected models. In additive impact factor on the SoVI is also done. The result is that there are regions that belong to the same class on both models such as Pemalang, there are regions that enter in different classes on both models such as Cilacap. The result also shows the model of Frigerio, I., et al. (2016) is more representative than the BNPB model (2012) by additionally considering the education and unemployment factors in determining the SoVI, while the BNPB model (2012) only includes internal factors such as age, gender. By considering education and unemployment factors, we get more detailed conditions about society from social vulnerability.
\end{abstract}

\section{INTRODUCTION}

\subsection{Background}

According to UNISDR (2017), vulnerability is the characteristics determined by physical, social, economic and environmental or processes which increase the susceptibility of an individual, a community, assets or systems to the impacts of hazards (Preventionweb team, 2017). Regions with high vulnerability have lower capacity of resilience and are less likely to "bounce back" after hazard strikes. To correctly use the vulnerability assessment data, it is important to build a thorough understanding about the factors that have impacts on the analysed outcomes, such that area with higher level of vulnerability can be correctly identified and proper actions can be taken.

Quantitative assessment helps to provide a reference to analyze the vulnerability of individual administrative units, as well as the spatial patterns for the whole region or even country. Various models have been proposed over the years. In Indonesia, the provisions on the determination of social vulnerability have been included in the Regulation of the Head of National Agency for Disaster Management (BNPB) Number 2 of 2012. The social vulnerability is measured by several factors, including population density, dependency ratio, sex ratio, disability ratio, and poverty ratio. The social vulnerability model proposed by Frigerio, I., et al (2016), on the other hand, considers factors of age, employment, education, and anthropization. As the two models may generate different outcomes due to the different choices of factors, the comparison of their results may further provide more in-depth knowledge about the quantitative assessment of social vulnerability.
To support the analysis of social vulnerability, the following perspectives are considered in this paper. The first is the historical disaster events occurred in the region, as the the number of casualties and economic loss may rise with the number and scale of the disasters. The second is the land use and people's livelihood. If these two factors work well, the unemployment rate can be effectively reduced. The final consideration is industry, as a solid and growing local industry can absorb a lot of manpower, reduce the number of unemployed people, as well as reduce the social vulnerability. More detailed discussion can be found in section 3 .

\subsection{Study area}

Central Java, one of 34 provinces in Indonesia, ranks fifth in population density in the country, has a population density of 1037 people $/ \mathrm{km}^{2}$, after Yogyakarta which has a population density of 1155 people $/ \mathrm{km}^{2}$. According to the Central Bureau of Statistics (BPS) data in 2017, the unemployment rate in Central Java is $4.57 \%$, while the average unemployment rate for the country is $5.13 \%$. From the past history, Central Java is a region under many types of hazard threats, such as floods, landslides, volcanic eruptions, earthquakes, etc. Among them, floods and landslides are the two most frequent types of disasters experienced by the people of Central Java. Landslides often occur after heavy rains that last for several days. Flood occurs when the facility and infrastructure cannot handle the accumulated rainfall. According to the vulnerability of land movement zone map from the Department of Energy and Mineral Resources (ESDM) of Central Java province in 2014, several areas, including Cilacap,

\footnotetext{
* Corresponding author
} 
Brebes, Banyumas, Kebumen, Purbalingga, and Wonosobo, are prone to the threat of the hazard because this region belongs to the mountain area in Central Java. The mountains include Mount Dieng, Mount Slamet, Mount Merbabu, and Mount Sindoro.

According to Aquinus (2018) in the media TrubusNews, during the year 2017 Central Java was experiencing landslides as much as 1091 times. Then continue in 2018, several major landslide events in Central Java have caused human causalties. For example, five people were killed and dozens more injured in Brebes in February 2018. In Purbalingga, four people were killed and a dozen missing around the same time. While the media mainly focuses on the number of people killed or injured, how those survived people deal with the after-disaster lives should also receive equivalent attentions. For more details about the condition of mass movement vulnerability in Central Java can be seen in Figure 1.

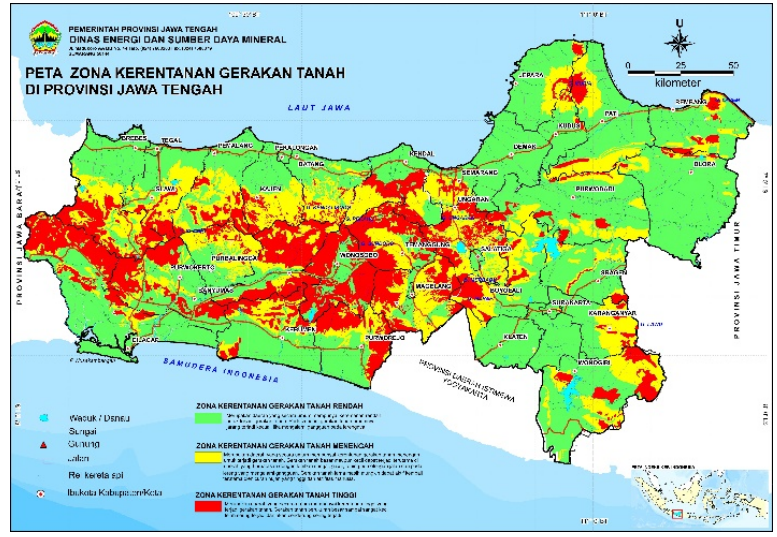

Figure 1. Map of mass movement prone zone in Central java (C) Department of Energy and Mineral Resources (ESDM) of Central Java province Copyright 2018

\section{METHODOLOGY}

\subsection{Data source}

The data used in this study is mainly collected from the Central Bureau of Statistics (BPS) of Central Java Province, supported by data from the Regional Development Planning Agency (BAPPEDA) and the Department of Energy and Mineral Resources (ESDM) in Central Java. The selected datasets are listed in Table 1.

\begin{tabular}{|l|l|}
\hline Data type & \multicolumn{1}{|c|}{ Generate data } \\
\hline Demographic & $\bullet \quad$ Population density \\
& $\bullet \quad$ Dependency ratio \\
Healthy & $\bullet \quad$ Sex ratio \\
Poverty & Disability ratio \\
Education & The poor ratio \\
Manpower & Education rate \\
\hline
\end{tabular}

Table 1. The kinds of data used in determining social vulnerability

\subsection{Model of Frigerio, I., et al. (2016)}

The research of Frigerio, I., et al. (2016) aimed to identify the spatial variability of social vulnerability for seismic hazard in Italy. The indicators proposed for measuring the social vulnerability are listed in Table 2 . This study is based on the 2001 data warehouse of the $14^{\text {th }}$ population and housing census that describes the demographic and social structure of the population residing in Italy.

\begin{tabular}{|c|c|c|}
\hline Variables & Indicators & $\begin{array}{l}\text { Impact on social } \\
\text { vulnerability }\end{array}$ \\
\hline $\begin{array}{l}\text { - } \quad \text { The rate of } \\
\text { children <14 years } \\
\text { - } \quad \text { The rate of elderly } \\
\text { - } 65 \text { years } \\
\text { - } \quad \text { Dependency ratio } \\
\text { - } \quad \text { Femalde labor force } \\
\text { employed } \\
\text { - } \quad \text { Labor force } \\
\text { employed } \\
\text { - } \quad \text { Unemployment } \\
\text { rate } \\
\text { - } \quad \text { Index of high } \\
\text { - } \quad \text { Index of low } \\
\text { education } \\
\text { - } \quad \text { Oopulation density } \\
\text { - } \quad \text { frbanized index } \\
\text { Quality residential use } \\
\text { Foreign resident }\end{array}$ & $\begin{array}{l}\text { Residential } \\
\text { property } \\
\text { Ethnicity }\end{array}$ & $\begin{array}{l}\text { Decrease } \\
\text { Increase }\end{array}$ \\
\hline
\end{tabular}

Table 2 . The indicators and variables of social vulnerability (Frigerio, I., et al, 2016)

For easier analysis and comparison, the value of each indicator is calculated following equation (1):

$$
Z_{i j}=\frac{\left(X_{i j}-M_{j}\right)}{S D_{j}}
$$

Where,

$\mathrm{Z}_{\mathrm{ij}} \quad=$ normalized value of different social vulnerable factors (j) in the certain assessed area (i);

$\mathrm{X}_{\mathrm{ij}} \quad=$ value of different social vulnerable factor $(\mathrm{j})$ in the certain assessed area (i);

$\mathrm{M}_{\mathrm{j}} \quad$ = average value of certain social vulnerable factor (j);

$\mathrm{SDj}=$ standard deviation of certain social vulnerable factor (j);

$\mathrm{i}=$ different area of assessment

$\mathrm{j} \quad=$ different social vulnerable factors

The calculated results are later used to compute SoVI following equation (2):

$$
\operatorname{SoVI}_{i}=\frac{\sum_{j=1}^{N} Z_{i j}}{N}
$$

Where,

SoVI $_{\mathrm{i}} \quad=$ Social Vulnerability Index of the assessed area

(i);

$\mathrm{Z}_{\mathrm{ij}} \quad=$ normalized value of different social vulnerable factors (j) in the certain assessed area (i);

$\mathrm{N} \quad=$ number of social vulnerable factors

$\mathrm{j}=$ different social vulnerable factors

According to the findings of Frigerio et al., not all of indicators are used for assessing the social vulnerability because only four factors, namely, age, employment, education, and anthropization, have more than one eigenvalue from the results of the Principal 
Component Analysis (PCA) method. Hence, only these four factors are considered in this study.

\subsection{BNPB (2012)}

Following the regulation of the Head of National Agency for Disaster Management Number 2 of 2012 on the general guidelines for disaster risk assessment, the social vulnerability for each administrative units are determined. Factors being considered include population density, sex ratio, dependency ratio, health (disability) and poverty.

\begin{tabular}{|c|c|c|c|c|c|}
\hline \multirow[t]{2}{*}{ Factors } & \multirow{2}{*}{$\begin{array}{c}\text { Weight } \\
(\%)\end{array}$} & \multicolumn{3}{|c|}{ Classes } & \multirow[t]{2}{*}{ Score } \\
\hline & & Low & moderate & high & \\
\hline $\begin{array}{l}\text { Population } \\
\text { density }\end{array}$ & 60 & $\begin{array}{l}<500 \\
\text { people } \\
/ \mathrm{km}^{2}\end{array}$ & $\begin{array}{l}500-1000 \\
\text { people/km² }\end{array}$ & $\begin{array}{l}>1000 \\
\text { people } \\
/ \mathrm{km}^{2}\end{array}$ & $\begin{array}{l}\text { Classes / } \\
\text { the } \\
\text { maximu }\end{array}$ \\
\hline Sex ratio & 10 & $<20 \%$ & $20 \%-40 \%$ & $>40 \%$ & $\mathrm{~m}$ value \\
\hline $\begin{array}{l}\text { Dependency } \\
\text { ratio }\end{array}$ & 10 & & & & $\begin{array}{l}\text { of the } \\
\text { class }\end{array}$ \\
\hline $\begin{array}{l}\text { Disability } \\
\text { ratio }\end{array}$ & 10 & & & & \\
\hline $\begin{array}{l}\text { The poor } \\
\text { ratio }\end{array}$ & 10 & & & & \\
\hline
\end{tabular}

Table 3. The factors of social vulnerability (BNPB, 2012)

And the equations used to obtain social vulnerability scores can be seen in equation (3):

$$
\begin{aligned}
& \text { SoVI }=\left(0.6 *\left(\frac{\log \left(\frac{\text { population density }}{0.01}\right)}{\log \left(\frac{100}{0.01}\right)}\right)\right)+(0.1 * \text { sex ratio })+ \\
& \quad(0.1 * \text { dependency ratio })+(0.1 * \text { disabbility ratio })+ \\
& (0.1 * \text { the poor ratio })
\end{aligned}
$$

Where,

SoVI

area

Sex ratio $\quad=$ the ratio of the number of comparisons between men and women

Dependency ratio $=$ the ratio of the number of comparisons between ages 15-64 years with ages 0-14 years and $>65$ years Disability ratio $=$ the ratio of the number of comparisons between disability population with a healthy population The poor ratio $=$ the ratio of the number of comparisons between the poor and the affluent population

\subsection{Re-classification}

Re-Classification can be used to eliminate or decrease the level of detail of data, so as to highlight the general or special patterns of the analyzed data (Susetyo, 2017). The most important choices when classifying data are to determine the classification method and the number of classes. In practice, there are two major types of re-classification methods are considered: user-driven classification and data-driven classification.

2.4.1. User-driven classification. In this method, users select their own attributes to be classified and customize their coding rules (Figure 2) or the range of intervals according to their tasks at hands. This is especially beneficial if a consensus agreement on the classification scheme can be reached and included in the national or domain specifications.

\begin{tabular}{|cll|}
\hline Code & Old category & New category \\
\hline 10 & Planned resi- & Residential \\
& dential & \\
20 & Industry & Commercial \\
30 & Commercial & Commercial \\
40 & Institutional & Public \\
50 & Transport & Public \\
60 & Recreational & Public \\
70 & Non built-up & Non built-up \\
80 & Unplanned & Residential \\
& residential & \\
\hline
\end{tabular}

Figure 2. User controlled classification method

2.4.2. Data-driven classification. Unlike the previous cases, reclassification methods belong to this category are mainly based on the data itself, so that the results are both data-dependent and case-dependent. Typical examples include equal intervals, equal frequency, standard deviation and others. Some examples can be found in Figure 3.

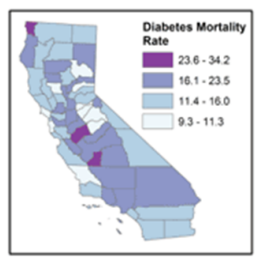

Optimized

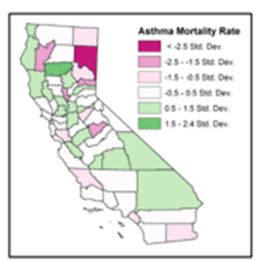

Standard Deviation

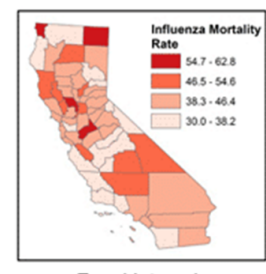

Equal Interval
Figure 3. Automated classification method

The choice of the classification method requires to consider the purpose for which the map will be used, the audience who will be using the map, and the distribution of the data (Gruver, 2012). Each types of classification methods are useful for mapping data according to particular types of statistical distributions. For example, the equal interval scheme works best for data with a rectangular distribution (i.e., approximately equal numbers of observations over the range of domains), while it is not very effective for highly skewed data as there may be many empty classes, forcing most observations into one or two classes, and leaving a very uninteresting map. On the other hand, the meanstandard deviation scheme works best for normally distributed data, but do not work very well for other types of distributions.

\section{RESULTS AND DISCUSSION}

The result of the determination of social vulnerability by two methods, classified by the data-driven classification method with equal interval scheme, is intended so that all classes formed can be filled evenly and no classes are empty. The differences will be discussed first from the perspective of historical disasters to find out if there is a relationship between regions with high vulnerability and regions with more historical hazards. Later discussion extends to the perspective of land use and industry to find out if the high vulnerability is related to the daily life of the people in terms of land use and industrial sectors. 


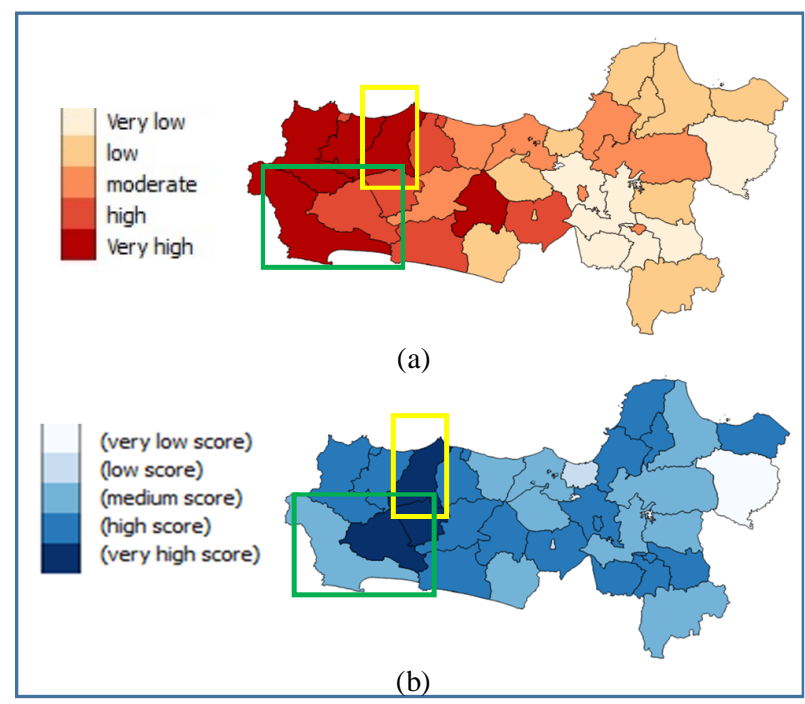

Figure 4. The results of a social vulnerability index; (a). Frigerio, I., et al. (2016); (b) BNPB (2012)

Figure 4 shows the comparative results of the two models, the yellow squares show the area having high social vulnerability values in both models. The area is Pemalang regency. While the green squares indicate the areas experiencing the different levels of social vulnerability from the two models. The area is Cilacap regency. The first model classfies the area into the highest vulnerability class, while the second model classifies the area into the class of medium vulnerability. The different classified results certainly imply different actions and priority to the government.

\subsection{The disaster perspective}

Table 4 lists the major historical disasters occurred in Pemalang and Cilacap. Most of the damage information are based on the damages to houses and damage to infrastructure, such as roads and electricity.

\begin{tabular}{|l|l|l|l|}
\hline Date & Disaster & \multicolumn{1}{|c|}{ Damage } & Location \\
\hline $12 / 31 /$ '17 & $\begin{array}{l}\text { Strong } \\
\text { wind }\end{array}$ & $\begin{array}{l}160 \text { of houses were } \\
\text { damaged and 14 of } \\
\text { people were injured } \\
\text { The water level } \\
\text { reached 120 m, } \\
\text { hundreds of houses } \\
\text { submerged, but no } \\
\text { residents who want to } \\
\text { evacuate } \\
\text { 429 of houses were } \\
\text { damaged and 2071 of } \\
\text { people evacuated } \\
5 \text { of houses damaged, } \\
\text { electricity died, } \\
\text { residents scattered } \\
\text { away from the beach } \\
\text { 210r of houses buried } \\
\text { in landslides }\end{array}$ & Pemalang \\
12/16/'17 & $\begin{array}{l}\text { Earthquacap } \\
\text { ke }\end{array}$ & Cilacap \\
11/14/'17 & $\begin{array}{l}\text { Flood } \\
\text { and } \\
\text { landslide } \\
\text { Tsunami }\end{array}$ & $\begin{array}{l}\text { as many as 34 people } \\
\text { died }\end{array}$ & Cilacap \\
07/19/'06 & Pemalang \\
\hline
\end{tabular}

Table 4. A number of disasters that attacked Pemalang and Cilacap
From Table 4 we can see that the damage experienced by Pemalang or Cilacap regency due to the disaster is physical damage such as damage to houses, damage to infrastructure such as roads, electricity. As for the social impact, it is necessary to evacuate a number of affected people. From there are two possible reasons for this condition. The first possibility because of the disaster experienced is a disaster with a small scale. The second possibility is that the residents are already familiar with the disaster, so they can take preparedness in dealing with the disaster so that it can minimize the number of victims and losses due to the disaster

According to Fauzi et al. (2017), there is a relationship between knowledge of disasters and disaster preparedness. Knowledge of disasters, in this case, can be obtained from various sources, can be obtained from formal education, from training held by relevant agencies, or from experience. If we look at the conditions in Indonesia, then the knowledge that comes from experience is the most prominent especially for floods, earthquakes, and landslides. And according to Larasati et al. (2017) Indonesian people, especially Wonogiri Regency, Central Java are most familiar with flood disaster than any other disaster.

So from the problem of disaster occurrence that often attacks Central Java, we can take one important factor related to social vulnerability. That is knowledge about the disaster. The higher the knowledge of a person or society about a disaster, the lower the degree of vulnerability. And as additional information, the level of community participation in education up to senior high school level in Pemalang Regency only reached $73.29 \%$, in Cilacap Regency only reached $75.20 \%$, while Central Java as a province has reached $83.90 \%$. This shows the participation rate of Pemalang and Cilacap people in terms of education in particular to senior high school level lower than the Central Java provincial community as a whole.

\subsection{Land use perspective}

To find out the high level of unemployment in an area, this research started from the match between the livelihoods of the people in the area with the land use. For more details about the distribution of land use in Pemalang regency can be seen in Figure 5.

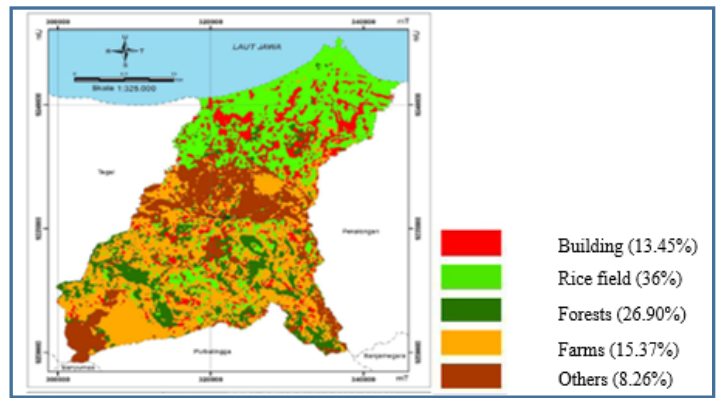

Figure 5. Land use in Pemalang, Central Java (The regional development planning agency, the regency of Pemalang. 2017)

The major land use in Pemalang is rice fields, covering 36\% of the total area of Pemalang, followed by forest, farm, and building. While the total area of rice field and farms exceeds half of the territory of Pemalang (if forest is included, the ratio increases to $78 \%$ ), only $31.62 \%$ of the population are farmers. According to the data from the regional development planning agency. 
Furthermore, the area of rice fields drops from 400 ha in 2013 to 383 ha in 2017 (Pemalang in number, 2017). This implies means more people prefers to work in other fields, such as industry and transportation, rather than becomes farmers. The economic and technology development is changing and even transforming the human activities in Pemalang. However, since rice fields and farms are still the dominant land use in Pemalang, vulnerability analysis on agriculture-related business (e.g., economic loss due to flood in the northern Pemalang) is still a major concern in this area.

A similar phenomenon is found in the data of Cilacap regency. Figure 6 shows the geographic distribution of the major land use categories in in Cilacap. Similar to the case in Pemalang, more than half of the total area of Cilacap is either rice field (30.27\%) or farm $(21.68 \%)$, and a larger portion of people are working in other domains instead of farmers.

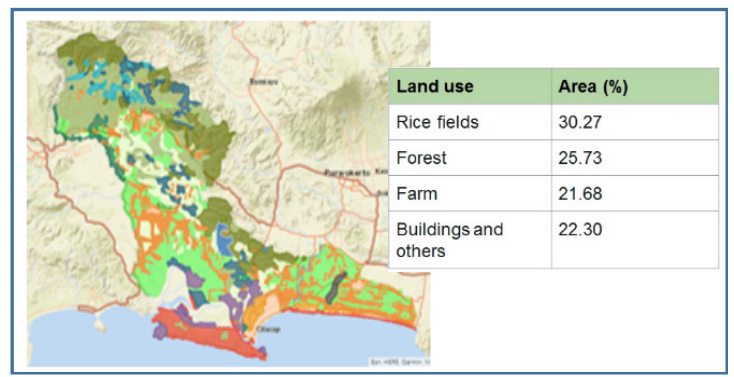

Figure 6. Land use in Cilacap, Central Java (Kanzulfawaid. 2011)

We can see from Figure 6, similar to Pemalang Regency that most of Cilacap Regency is rice field with an area of $30.27 \%$. Followed by forest, farm, and the rest are buildings and others. But like Pemalang also many Cilacap residents who do not work in the agricultural sector. People are more likely to work in other sectors such as transportation and others including unemployment.

\subsection{Industrial perspective}

With the economic transformation from the agriculture-related sector to the industrial sector, the land use of building also increases. This also affects the workforce in different sectors. Figure 6 shows the number of industrial workers in Pemalang from 2008 to 2013 .

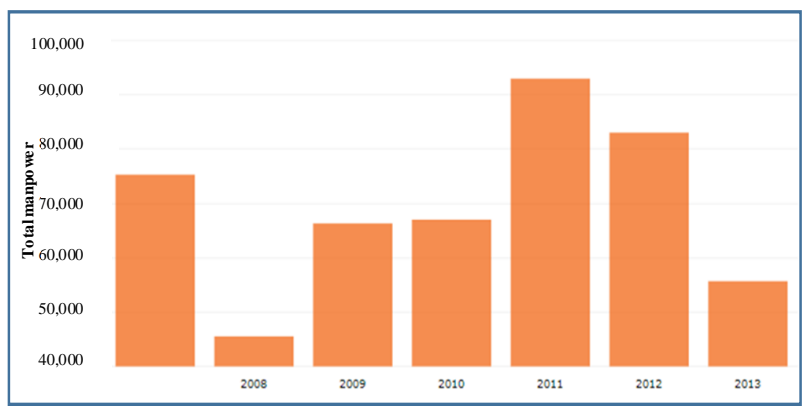

Figure 7. Number of workers in the industrial sector in Pemalang (Katadata team, 2016)

From Figure 7, we can see that the industry in Pemalang is able to absorb labor up to 50 thousand more in 2013. And since 2011 continues to decline, where in 2011 the number of workers reached 93 thousand, then in 2012 fell to 83 thousand. While the number of population is quite the opposite from year to year increase. Recorded in 2011 the number of residents in Pemalang District as much as 1,268,320 people, then increased in 2012 to $1,273,530$ people, and last in 2013 increased again to 1,281,470 people. This can indirectly increase the number of unemployed. The unemployment rate at Pemalang in 2011 is 7.37 and then dropped in 2012 to 4.85 , and then up again in 2013 to 6.48. The graph of the number of workers, the population, and the unemployment rate can be seen in Figure 8 .

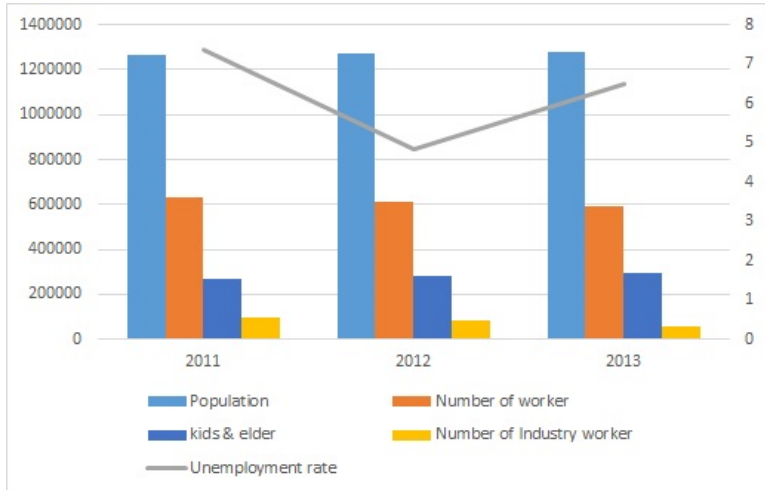

Figure 8. Graph of workers, population, and unemployment rate in Pemalang

For more details about the number of industrial workers in Cilacap regency from 2008 to 2013 can be seen in Figure 9.

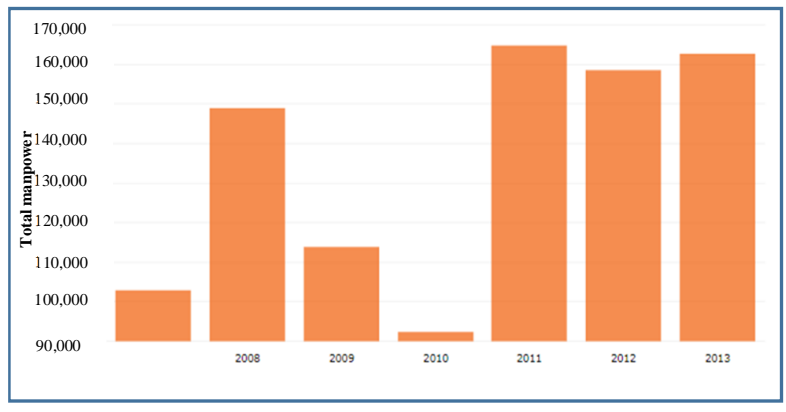

Figure 9. Number of workers in the industrial sector in Cilacap (Katadata team, 2016)

From Figure 9 we can see that the industry in Cilacap is able to absorb more manpower than Pemalang to reach 160 thousand more in 2013. In 2011 had high reached 164 thousand people, then had fallen in 2012 to 158 thousand people, which eventually returned in 2013. In contrast to conditions in Pemalang, in Cilacap the increase in population along with the increase in the number of workers in the industrial sector. Where in 2011 the population in Cilacap reached 1,644,990 people, then increased in 2012 to $1,656,870$ people, and in 2013 to $1,710,300$ people. So the unemployment rate in Cilacap also comes down with the increasing number of industrial workers. The unemployment rate in Cilacap in 2011 was 10.82, then decreased in 2012 to 7.29 , and in 2013 to 6.68 . The graph of the number of workers, the population, and the unemployment rate can be seen in Figure 10. 


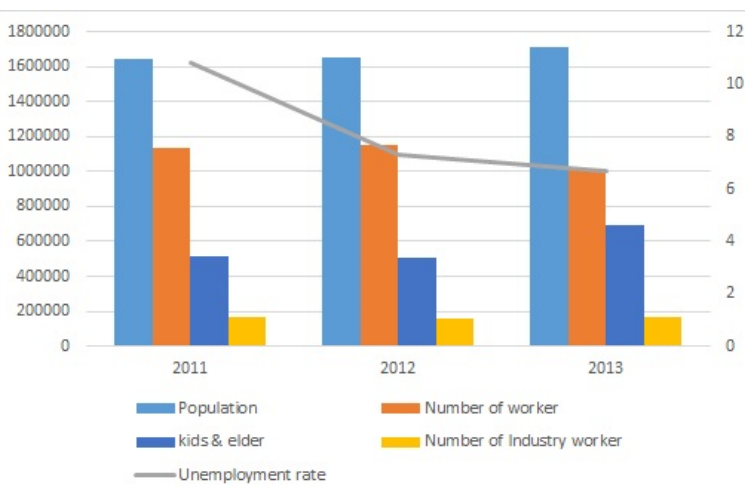

Figure 10. Graph of workers, population, and unemployment rate in Cilacap

So from the perspective of land use and the industry, it can be seen that there is a problem of discrepancy between most land use and most of the livelihoods of the population. This problem can be a trigger of vulnerability. Because people who do not have jobs tend to be lower self-confidence than those who have jobs. And low self-confidence of people who tend to be more vulnerable in the face of problems, including disaster than, those whose confidence is high.

From this, we can take one important factor necessary in determining social vulnerability. That factor is the ability of a person, group, or society to protect/defend themselves in the face of problems or disasters with all the abilities/advantages they have. The greater the ability possessed the lower the level of vulnerability.

\subsection{Scheme of the idea of factors of social vulnerability}

From historical disaster incidents that attacked Pemalang and Cilacap, and data from land use and industrial sector, and availability of employment, it can be concluded a number of important factors related to the determination of SoVI. These factors are grouped into three main factors:

3.4.1. Internal factors. That is the factor inherent in the human being as a social being naturally, for example; population, population density, gender, age, health, and others.

3.4.2. The ability to recognize disasters. The capabilities possessed by humans both individually and in groups in recognizing or understanding disasters that will or are being faced. This factor is influenced by the level of education, training that has been followed, or experience.

3.4.3. The ability to take preparedness. The ability to deal with disasters is a capability that people possess either individually or in groups to take preventive or rescue measures in the face of disasters. This factor is influenced by; owned jobs, income owned, residential houses and other factors.

If described in the form of a diagram, then it can be seen in Figure 11 .

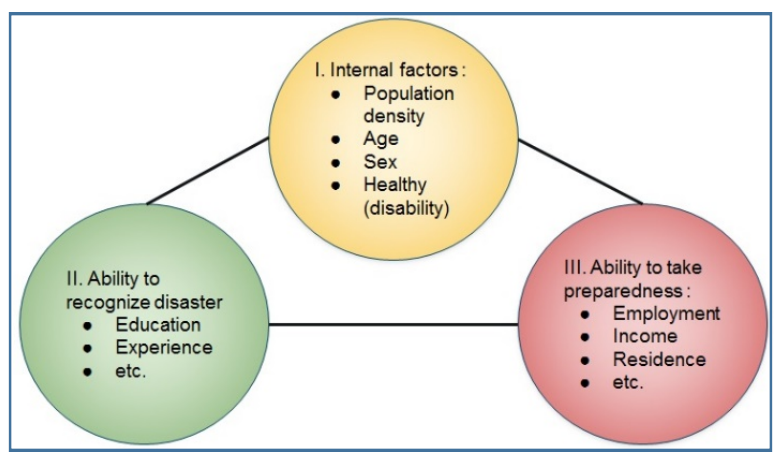

Figure 11. Diagram of factors affecting SoVI

3.5 The differences between the model of Frigerio, I., et al. (2016) and BNPB (2012)

Having known the most influential factors in determining SoVI, it can be obtained the difference between the model of SoVI Frigerio, I., et al. (2016) and model of BNPB (2012). There are two important differences between the models of SoVI Frigerio, I., et al. (2016) and model of BNPB (2012)

After understanding the impact factors for determining SoVI, this section compares the outcomes respectively based on the model of SoVI proposed by Frigerio, I., et al. (2016) and the model of BNPB (2012). The model of BNPB (2012) uses only internal factors in the determination of SoVI, while the models of SoVI Frigerio, I., et al. (2016) includes additional factors such as education and occupation in the determination of SoVI. Social vulnerability is still less representative if it refers only to the internal factors of human beings as social beings, the fact indicates that there are many other factors that greatly affect social vulnerability, as well as issues of education and employment. Therefore, in this case, the model of Frigerio, I., et al. tends to be better because it incorporates other factors, in addition to internal factors in arranging the model

There are some districts that has high social vulnerability scores on the first model but has middle social vulnerability score on the second model. One example is Cilacap regency. The population density in Cilacap regency is 797 people $/ \mathrm{km}^{2}$, relatively lower when compared to that of Central java (1092 people $/ \mathrm{km}^{2}$ ). Meanwhile, the unemployment rate in Cilacap is $8.01 \%$, relatively higher than other areas with high population density, such as Pemalang (6.53\%), and Central java (4.97\%). As the education and unemployment rate both have impacts on the social vulnerability, the conflicted determination between the two models imply the model proposed by Frigerio, I., et al. can recognize impacts of these factors and provide more clues for assessing social vulnerability.

\section{CONCLUSION}

From the analysis results obtained conclusion as follows:

1. The vulnerability is one of the defining components of disaster risk. Therefore need to be considered to be reduced, in order to reduce the risk of disaster as well.

2. One way to reduce social vulnerabilities is to consider the factors that compose. And based on the analysis result obtained three main factors that can arrange social vulnerability that is; internal factors, ability to 
recognize disaster and ability to take preparedness.

3. The model of Frigerio, I., et al (2016) with the more diverse factors tends to be more giving more clues to assessing social vulnerability, than the model of BNPB (2012) which only uses internal factors.

4. It is necessary to do research related to the comparison of these two models or new models suggested in other parts of Indonesia or regions in other countries so that the assessment of these models can be tested in different areas of different conditions.

\section{REFERENCES}

Aquinus, T., 2018. Central Java was hit by Landslide Disaster a total of 1,091 times throughout 2017. TrubusNews. https://news.trubus.id/post/jawa-tengah-dilanda-bencana-tanahlongsor-sebanyak-1-091-kali-sepanjang-2017-5645

Central Bureau of Statistics of Central Java, 2017. Open $\begin{array}{lllll}\text { unemployment } & \text { rate } & 2007 & - & \end{array} 2017$. https://jateng.bps.go.id/linkTableDinamis/view/id/34

Department of Energy and Mineral Resources (ESDM) of Central Java province, 2014. Land Movement Vulnerability Map of Central Java. https://esdm.jatengprov.go.id/Peta-KerentananGerakan-Tanah-Jawa-Tengah.html

Fauzi, Riski, A., Hidayati, A., Subagyo, D. O., Sukini, and Latif, N., 2017. "Relationship building of disaster knowledge with community preparedness in Wonogiri regency in dealing earthquake." Proceedings of National Seminar of UMS 2017. https://publikasiilmiah.ums.ac.id/bitstream/handle/11617/9039/s emnasgeo2017_28.pdf?sequence $=1$

Frigerio, I. et al, 2016. A GIS-based approach to identify the spatial variability of social vulnerability to seismic hazard in Italy. Applied Geography $74 \quad$ (2016) 12 - 22. http://daneshyari.com/article/preview/83108.pdf

Gruver, A., 2012. Classification scheme. GEOG 486: Cartography and Visualization. https://www.eeducation.psu.edu/geog486/node/1865

Kanzulfawaid, 2011. Land use map of Cilacap regency. https://www.arcgis.com/home/webmap/viewer.html?webmap=0 ef7df4bc72d4bbea736d7bbf0f11e36

Katadata team, 2016. Number of Workers in the Industrial Sector in Pemalang Regency, Central Java 2007 - 2013. https://databoks.katadata.co.id/datapublish/2016/05/12/jumlahpekerja-di-sektor-industri-di-kabupaten-pemalang-jawa-tengah2007-2013

Katadata team, 2016. Number of Workers in the Industrial Sector in Cilacap Regency, Central Java 2007 - 2013. https://databoks.katadata.co.id/datapublish/2016/05/12/jumlahpekerja-di-sektor-industri-di-kabupaten-cilacap-jawa-tengah2007-2013

Larasati, Y., Utami, M., H., Pramita, R., D., and Surya, D., 2017. "Level of Community knowledge on flood, Earthquake, a landslide in Wonogiri regency." Proceedings of National $\begin{array}{ccc}\text { Seminar } & \text { of } & \end{array}$ https://publikasiilmiah.ums.ac.id/bitstream/handle/11617/9037/s emnasgeo2017_26.pdf?sequence $=1$
National Agency for Disaster Management, 2012. The regulation of the head of the National Disaster Agency for Management Number 2 of 2012 on general guidelines for disaster risk assessment. https://www.academia.edu/8758982/Peraturan_Kepala_BNPB_ No_2_Tahun_2012_tentang_Pedoman_Umum_Pengkajian_Risi ko_Bencana

Preventionweb team, 2017. Component of risk: vulnerability. https://www.preventionweb.net/risk/vulnerability

Susetyo, C., 2017. Spatial analysis: Classification. http://www.pwktech.info/analisa-spasial/sa_3_classification/

The regional development planning agency, the regency of Pemalang, 2017. Land use map, Pemalang. http://sitrw.bappedapemalang.info/content.php?query=penggun aan_lahan

The regional development planning agency, the regency of Pemalang, 2017). Population in Pemalang. http://sitrw.bappedapemalang.info/content.php?query=kependu dukan 